\title{
Lysinibacillus xylanilyticus sp. nov., a xylan- degrading bacterium isolated from forest humus
}

Correspondence Jung-Hoon Yoon jhyoon@kribb.re.kr

\author{
Chang Soo Lee, Yong-Taek Jung, Sooyeon Park, Tae-Kwang Oh \\ and Jung-Hoon Yoon
} Korea Research Institute of Bioscience and Biotechnology (KRIBB), PO Box 115, Yusong, Taejon,
Republic of Korea

\begin{abstract}
A novel xylan-degrading bacterium, designated $\mathrm{XDB9}^{\top}$, was isolated from forest humus collected from Gyeryong Mountain in Korea. Cells were Gram-positive, aerobic, motile and endosporeforming rods. A neighbour-joining phylogenetic tree based on 16S rRNA gene sequences showed that strain $\mathrm{XDB9}^{\top}$ was most closely related to members of the genus Lysinibacillus. 16S rRNA gene sequence similarities between strain $\mathrm{XDB9}^{\top}$ and the type strains of species of the genus Lysinibacillus ranged from 98.0 to $98.5 \%$. The cell-wall peptidoglycan type of strain $\mathrm{XDB9}^{\top}$ was $A 4 \alpha$, which is based on L-Lys-D-Asp. Strain $\mathrm{XDB9}^{\top}$ contained iso- $\mathrm{C}_{15: 0}$ and $\mathrm{C}_{16: 1} \omega 7 \mathrm{c}$ alcohol as the major fatty acids and MK-7 as the predominant menaquinone. The major polar lipids were diphosphatidylglycerol, phosphatidylglycerol and phosphatidylethanolamine. The DNA G +C content was 37.2 mol\%. The DNA-DNA hybridization results and differential phenotypic properties showed that strain $\mathrm{XDB}^{\top}{ }^{\top}$ could be distinguished from recognized species of the genus Lysinibacillus. It was concluded that strain $X D B 9^{\top}$ represents a new taxon for which the name Lysinibacillus xylanilyticus sp. nov. is proposed. The type strain is $\mathrm{XDB9}^{\top}(=\mathrm{KCTC}$ $13423^{\top}=$ CCUG $57438^{\top}$ ).
\end{abstract}

The genus Lysinibacillus was proposed by Ahmed et al. (2007) by the description of one novel species and the reclassification of two Bacillus species on the basis of a polyphasic taxonomic study, and especially with regard to characteristics such as cell-wall peptidoglycan structure. At the time of writing, the genus Lysinibacillus was composed of four species with validly published names: Lysinibacillus boronitolerans, Lysinibacillus fusiformis and Lysinibacillus sphaericus (Ahmed et al., 2007) and Lysinibacillus parviboronicapiens (Miwa et al., 2009).

During the course of a study on the diversity of xylandegrading bacteria from natural environments, a novel bacterial strain, $\mathrm{XDB} 9^{\mathrm{T}}$, was isolated from forest humus. Xylan, a polymer of $\beta$-1,4-D-xylopyranosyl units, is one of the most ubiquitous polysaccharides in nature and a main constituent of hemicellulose, which is found in the cell walls of plants (Timmell, 1967). Xylan-degrading bacteria have been isolated in order to screen for xylanases, such as $\beta$-1,4-D-xylan xylanohydrolase and $\beta$-1,4-D-xylan xylohydrolase, which are useful in the food and pulp industries (Coughlan \& Hazlewood, 1993).

For the screening of xylan-degrading bacteria, forest humus was collected from Gyeryong Mountain, Taejon,

Abbreviation: DNS, dinitrosalicylic acid.

The GenBank/EMBL/DDBJ accession number for the 16S rRNA gene sequence of strain $\mathrm{XDB9}^{\top}$ is FJ477040.
Korea. The samples were serially diluted in $0.85 \%(\mathrm{w} / \mathrm{v})$ saline solution and then aliquots of each serial dilution were spread onto solid medium containing $0.5 \%(\mathrm{w} / \mathrm{v})$ birch wood xylan (Sigma) and $1.5 \%(\mathrm{w} / \mathrm{v})$ Noble agar (Difco). The medium was incubated for 7 days at $25{ }^{\circ} \mathrm{C}$ under aerobic conditions. One of the isolates, $\mathrm{XDB9}^{\mathrm{T}}$, was selected and subcultivated on trypticase soy agar (TSA; Difco) at $30{ }^{\circ} \mathrm{C}$ for further study. L. boronitolerans JCM $21713^{\mathrm{T}}$, L. fusiformis KACC $10903^{\mathrm{T}}$ and L. sphaericus KCTC $3346^{\mathrm{T}}$ were used as reference strains for phenotypic characterization, cellular fatty acid analysis and DNADNA hybridization. L. parviboronicapiens KCTC $13154^{\mathrm{T}}$ was also used as a reference strain for phenotypic characterizations and DNA-DNA hybridization.

To investigate the xylan-degrading activity of strain $\mathrm{XDB9}^{\mathrm{T}}$, Congo red (Wood et al., 1988) and dinitrosalicylic acid (DNS) methods (Miller, 1959) were used. For the DNS test, strain $\mathrm{XDB}^{\mathrm{T}}$ was cultured and suspended in $100 \mathrm{ml}$ of $50 \mathrm{mM}$ potassium phosphate buffer ( $\mathrm{pH} \mathrm{6.5)}$ and the inoculum density was adjusted to a McFarland standard of 0.5. Birch wood xylan ( $1 \mathrm{~g}$ ) was added and the mixture was incubated for $6 \mathrm{~h}$ at $30{ }^{\circ} \mathrm{C}$. A $100 \mu \mathrm{l}$ aliquot of the mixture was then transferred into an Eppendorf tube, $1 \mathrm{ml}$ DNS reagent was added and the tube was heated in a boiling water bath for $10 \mathrm{~min}$. Finally, the absorbance was measured at $575 \mathrm{~nm}$ with a spectrophotometer (DU800; Beckman Coulter). 
Cell morphology and motility were examined by light microscopy (E600; Nikon) and transmission electron microscopy (CM-20; Philips). The Gram reaction was performed using the bioMérieux Gram-stain kit according to the manufacturer's instructions. Growth at various temperatures $\left(4,10,15,20,25,30,37,40\right.$ and $\left.45{ }^{\circ} \mathrm{C}\right)$ was measured on TSA. The $\mathrm{pH}$ range for growth was determined in trypticase soy broth (TSB; Difco) adjusted to various $\mathrm{pH}$ values $(\mathrm{pH} 4.0-10.0$, in increments of $0.5 \mathrm{pH}$ units) by the addition of $\mathrm{HCl}$ or $\mathrm{Na}_{2} \mathrm{CO}_{3}$. Growth at various $\mathrm{NaCl}$ concentrations $(0,0.5,1.0,2.0,3.0,4.0,5.0$, 6.0 and $7.0 \%, \mathrm{w} / \mathrm{v}$ ) was investigated using TSB prepared according to the formula of the Difco medium except that $\mathrm{NaCl}$ was excluded. Oxidase and catalase activities and hydrolysis of casein, hypoxanthine, starch, Tweens 20,40 , 60 and 80, tyrosine and xanthine were tested on appropriate media and substrates as described by Cowan \& Steel (1965). Hydrolysis of aesculin and reduction of nitrate were examined as described by Lányí (1987). Utilization of various substrates, enzyme activities and other physiological and biochemical properties were tested by using the API 20E, API 50CH and API ZYM systems (bioMérieux) according to the manufacturer's instructions. The cells were suspended in AUX medium to inoculate the API $50 \mathrm{CH}$ system. Resistance to antibiotics was assessed by spreading bacterial suspension on TSA and applying paper discs impregnated with the following ( $\mu$ g per disc unless otherwise stated): polymyxin B (100 U), streptomycin (50), penicillin G (20 U), chloramphenicol (100), ampicillin (10), cephalothin (30), gentamicin (30), novobiocin (5), tetracycline (30), kanamycin (30), lincomycin (15), oleandomycin (15), neomycin (30) and carbenicillin (100). Boron tolerance was tested as described by Ahmed et al. (2007) at concentrations of 0,50, 100 and $150 \mathrm{mM}$.

For cellular fatty acid analysis, cell biomass was harvested from TSA plates after cultivation for $24 \mathrm{~h}$ at $28^{\circ} \mathrm{C}$. Cell biomass of strain $\mathrm{XDB}^{\mathrm{T}}$ for the analyses of cell-wall components, isoprenoid quinones and polar lipids and for DNA extraction was obtained from cultures grown in TSB at $30{ }^{\circ} \mathrm{C}$. The fatty acids were extracted and the fatty acid methyl esters were prepared according to the standard protocol of the MIDI/ Hewlett Packard Microbial Identification System (Sasser, 1990). The cell-wall peptidoglycan was extracted and purified as described by Schleifer \& Kandler (1972). The peptidoglycan amino acids were determined using an automated amino acid analyser (L-8500A; Hitachi). Isoprenoid quinones were extracted as described by Komagata \& Suzuki (1987) and analysed using reversed-phase HPLC equipped with a YMC ODS-A $(250 \times 4.6 \mathrm{~mm})$ column. Polar lipids were extracted and identified by two-dimensional TLC followed by spraying with appropriate detection reagents as described by Minnikin et al. (1984). Extraction of chromosomal DNA and PCRmediated amplification and sequencing of the 16S rRNA gene sequence were performed as described previously (Yoon et al., 1996, 1998, 2003).

The 16S rRNA gene sequence was aligned with sequences retrieved from EMBL by using CLUSTAL_X (Thompson $e t$ al., 1997) and edited by using BioEdit (Hall, 1999). Phylogenetic trees were constructed on the basis of the neighbour-joining (Saitou \& Nei, 1987), maximumlikelihood (Felsenstein, 1981) and maximum-parsimony (Kluge \& Farris, 1969) algorithms with MEGA version 3.1 (Kumar et al., 2004). The stability of relationships in the neighbour-joining tree was evaluated by bootstrap analysis (Felsenstein, 1985) based on 1000 replications. The DNA $\mathrm{G}+\mathrm{C}$ content was determined as described by Tamaoka \& Komagata (1984) with the modification that, after hydrolysis of the DNA, the resultant nucleotides were analysed by reversed-phase HPLC. DNA-DNA hybridization was performed fluorometrically by the method of Ezaki et al. (1989) using photobiotin-labelled DNA probes and 96-well plates (Nunc). Hybridization was performed with five replications for each sample. The highest and lowest values obtained for each sample were excluded and the means of the remaining three values were quoted as DNA-DNA relatedness values.

Morphological, cultural, physiological and biochemical characteristics of strain $\mathrm{XDB}^{\mathrm{T}}$ are given in the species description and in Table 1. The 16S rRNA gene sequence of strain $\mathrm{XDB}^{\mathrm{T}}$ determined in this study consisted of 1349 nucleotides and showed the closest affiliations to those of members of the genus Lysinibacillus (Fig. 1). In the phylogenetic trees based on 16S rRNA gene sequences, strain $\mathrm{XDB}^{\mathrm{T}}$ formed an evolutionary lineage within the cluster comprising species of the genus Lysinibacillus, clustering most closely with $L$. boronitolerans $10 \mathrm{a}^{\mathrm{T}}$ with a bootstrap resampling value of $88 \%$ (Fig. 1). The relationship between strain $\mathrm{XDB}^{\mathrm{T}}$ and $L$. boronitolerans $10 \mathrm{a}^{\mathrm{T}}$ was also found in the trees constructed using the maximumlikelihood and maximum-parsimony algorithms (Fig. 1). $16 \mathrm{~S}$ rRNA gene sequence similarity values between strain $\mathrm{XDB9}^{\mathrm{T}}$ and the type strains of species of the genus Lysinibacillus ranged from $98.0 \%$ (L. sphaericus NRRL $\mathrm{B}-23268^{\mathrm{T}}$ ) to $98.5 \%$ (L. fusiformis NRRL NRS-350 ${ }^{\mathrm{T}}$ and L. boronitolerans $\left.10 \mathrm{a}^{\mathrm{T}}\right)$.

Quantitative analysis of the cell-wall peptidoglycan showed that strain XDB9 ${ }^{\mathrm{T}}$ and L. boronitolerans JCM $21713^{\mathrm{T}}$ had similar molar ratios of alanine, aspartic acid, glutamic acid and lysine (approximately 1.43:0.43:1.0:0.33 and $1.45: 0.65: 1.0: 0.45$, respectively). The smaller amounts of lysine and aspartic acid were due to the presence of the stable peptide L-Lys-D-Asp. From these data, it was concluded that strain $\mathrm{XDB}^{\mathrm{T}}$ had the peptidoglycan type A $4 \alpha$, which is based on L-Lys-D-Asp, as described by Schleifer \& Kandler (1972). This supported the result of the phylogenetic analysis, which showed an affiliation of strain $\mathrm{XDB9}^{\mathrm{T}}$ to the genus Lysinibacillus, because the $\mathrm{A} 4 \alpha$ peptidoglycan type is a key marker used to discriminate the genus Lysinibacillus, as well as the genus Kurthia, from other members of Bacillus group 2 (Shaw \& Keddie, 1983; Stackebrandt et al., 1987; Claus \& Fritze, 1989; Ash et al., 1991; Rheims et al., 1999; Nakamura et al., 2002). The predominant isoprenoid quinone detected in strain $\mathrm{XDB} 9^{\mathrm{T}}$ was menaquinone-7 (MK-7), which is the same as that 


\section{Table 1. Differential phenotypic characteristics of strain $X D B 9^{\top}$ and other Lysinibacillus species}

Species: 1, Lysinibacillus xylanilyticus sp. nov. XDB9 ${ }^{\mathrm{T}}$ (data from this study); 2, L. boronitolerans JCM 21713 ${ }^{\mathrm{T}}$ (Ahmed et al., 2007; this study); 3 , L. fusiformis KACC $10903^{\mathrm{T}}$ (Priest et al., 1988; this study); 4, L. parviboronicapiens KCTC $13154^{\mathrm{T}}$ (Miwa et al., 2009; this study); 5, L. sphaericus KCTC $3346^{\mathrm{T}}$ (Claus \& Berkeley, 1986; this study). All species are Gram-positive and endospore-forming rods and give positive reactions in tests for motility, catalase activity, resistance to ampicillin, polymyxin B, cephalothin and lincomycin, and utilization of glucose, fructose, cellobiose, gluconate, 2ketogluconate and 5-ketogluconate. All species are negative for production of $\mathrm{H}_{2} \mathrm{~S}$ and indole, reduction of nitrate and lysine decarboxylase and ornithine decarboxylase activities (data are taken from the reference species used in this study), $\mathrm{NaCl}$ requirement, resistance to carbenicillin, kanamycin, neomycin, oleandomycin, penicillin $\mathrm{G}$ and tetracycline, utilization of $\mathrm{N}$-acetylglucosamine, adonitol, amygdalin, D-arabinose, D- and Larabitol, arbutin, dulcitol, erythritol, D- and L-fucose, gentiobiose, glycerol, glycogen, inositol, inulin, lactose, D-lyxose, mannitol, melezitose, raffinose, salicin, sorbose, starch, D-tagatose, turanose, xylitol, L-xylose, methyl $\alpha$-D-glucoside, methyl $\alpha$-D-mannoside and methyl $\beta$-D-xyloside and acid production from D-arabinose, inositol, melibiose, L-rhamnose and D-sorbitol. +, Positive; - , negative; ND, no data available.

\begin{tabular}{|c|c|c|c|c|c|}
\hline Characteristic & 1 & 2 & 3 & 4 & 5 \\
\hline Cell size $(\mu \mathrm{m})$ & $0.8-1.0 \times 3.0-5.0$ & $0.8-1.5 \times 3.0-5.0$ & $\mathrm{ND}$ & $0.5-1.0 \times 2.0-5.0$ & $0.6-1.0 \times 1.5-5.0$ \\
\hline Spore shape and position ${ }^{\star}$ & $\mathrm{R}, \mathrm{T}, \mathrm{B}$ & $\mathrm{R} / \mathrm{O}, \mathrm{T}, \mathrm{B}$ & $\mathrm{R}, \mathrm{C} / \mathrm{T}, \mathrm{B}$ & $\mathrm{R}, \mathrm{T}, \mathrm{B}$ & $\mathrm{R}, \mathrm{T}, \mathrm{B}$ \\
\hline $10{ }^{\circ} \mathrm{C}$ & + & - & - & + & + \\
\hline $40{ }^{\circ} \mathrm{C}$ & + & + & + & - & + \\
\hline $6 \%(\mathrm{w} / \mathrm{v}) \mathrm{NaCl}$ & - & - & + & + & - \\
\hline Boron tolerance $(\mathrm{mM})$ & 0 & 150 & $60 \dagger$ & 50 & $75 \dagger$ \\
\hline Voges-Proskauer test $\ddagger$ & - & + & - & + & - \\
\hline Oxidase $\neq$ & + & + & + & - & + \\
\hline Arginine dihydrolase $\ddagger$ & - & + & - & - & - \\
\hline$\beta$-Galactosidase & - & - & - & - & + \\
\hline Urea & - & + & + & + & - \\
\hline \multicolumn{6}{|l|}{ Resistance to: $\ddagger$} \\
\hline Chloramphenicol & - & - & + & + & - \\
\hline Gentamicin & - & + & - & - & + \\
\hline Novobiocin & + & + & - & - & - \\
\hline Streptomycin & + & - & + & + & + \\
\hline \multicolumn{6}{|l|}{ Utilization of: $\ddagger$} \\
\hline Aesculin & + & + & - & + & - \\
\hline L-Arabinose & + & - & - & - & + \\
\hline Citrate & + & + & + & - & + \\
\hline D-Galactose & - & - & - & - & + \\
\hline D-Xylose & + & - & - & - & + \\
\hline
\end{tabular}

${ }^{\star} \mathrm{B}$, Bulging; $\mathrm{C}$, central; $\mathrm{O}$, oval or slightly oval; $\mathrm{R}$, round; $\mathrm{T}$, terminal.

$\dagger$ Data from Ahmed et al. (2007).

$\$$ Data were taken from this study for the reference species as described previously.

found in members of the genus Lysinibacillus (Ahmed et al., 2007; Miwa et al., 2009). The cellular fatty acid profile of strain $\mathrm{XDB}^{\mathrm{T}}$ is shown in Table 2 together with those of three Lysinibacillus species, also analysed in this study, and L. parviboronicapiens BAM-582 $2^{\mathrm{T}}$, analysed by Miwa et al. (2009). The major fatty acids ( $>10 \%$ of total fatty acids) 


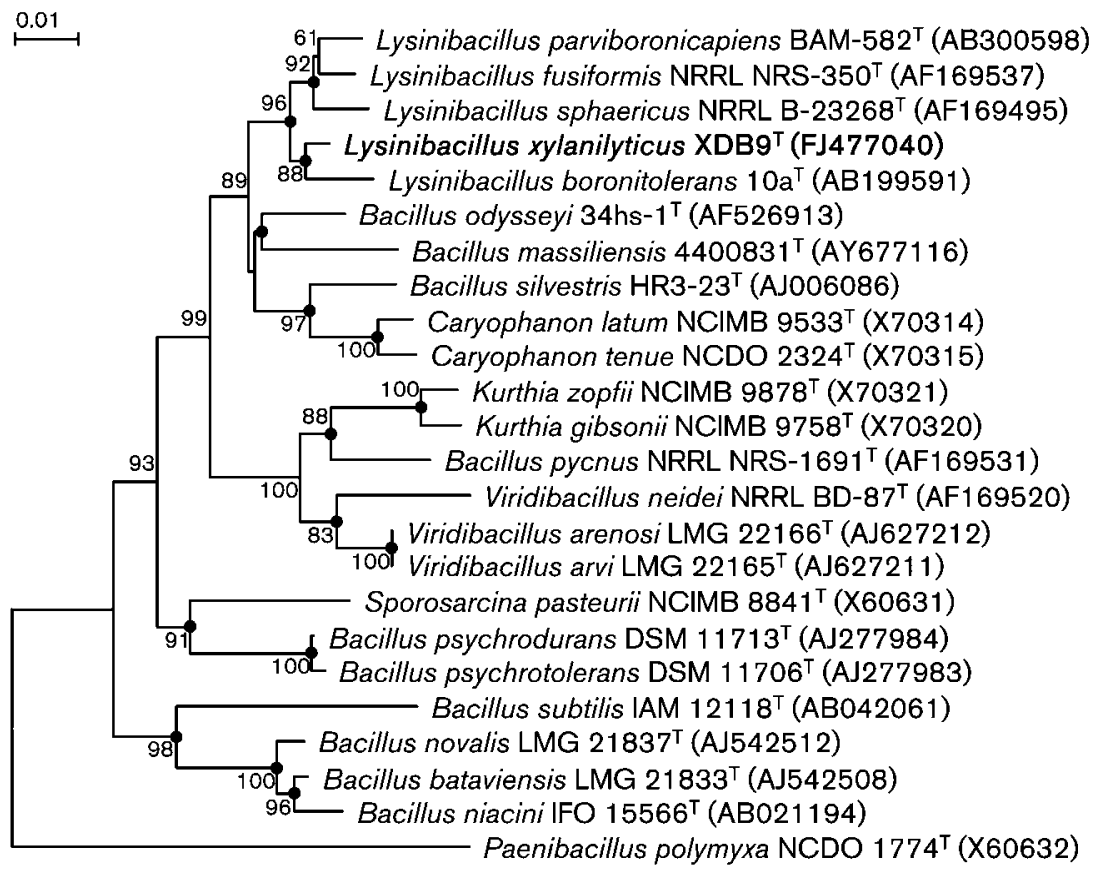

Fig. 1. Neighbour-joining phylogenetic tree based on 16S rRNA gene sequences showing the positions of strain $\mathrm{XDB}^{\top}$ and some other related taxa. Bootstrap values $(>50 \%)$ based on 1000 replications are shown at branch nodes. Filled circles indicate that the corresponding nodes were also recovered in the trees generated with the maximum-likelihood and maximum-parsimony algorithms. Paenibacillus polymyxa NCDO $1774^{\top}$ was used as an outgroup. Bar, 0.01 substitutions per nucleotide position.
Table 2. Cellular fatty acid contents of strain $X D B 9^{\top}$ and the type strains of species of the genus Lysinibacillus

Strains: 1, Lysinibacillus xylanilyticus sp. nov. $\mathrm{XDB}^{\mathrm{T}} ; 2, \quad L$. boronitolerans JCM $21713^{\mathrm{T}}$; 3, L. fusiformis KACC $10903^{\mathrm{T}}$; 4, L. parviboronicapiens BAM-582 ${ }^{\mathrm{T}}$; 5, L. sphaericus KCTC $3346^{\mathrm{T}}$. - , Not detected or not described. Data for taxa 1-3 and 5 are from this study; data for taxon 4 are from Miwa et al. (2009). Fatty acids that represented $<1.0 \%$ in all strains are omitted.

\begin{tabular}{|c|c|c|c|c|c|}
\hline Fatty acid (\%) & 1 & 2 & 3 & 4 & 5 \\
\hline \multicolumn{6}{|l|}{ Straight-chain } \\
\hline $\mathrm{C}_{16: 0}$ & 1.2 & 1.8 & 1.3 & 4.1 & 1.8 \\
\hline $\mathrm{C}_{20: 0}$ & - & - & 6.7 & - & - \\
\hline \multicolumn{6}{|l|}{ Branched } \\
\hline iso- $\mathrm{C}_{11: 0}$ & 8.8 & - & - & - & - \\
\hline iso- $\mathrm{C}_{14: 0}$ & 2.3 & 1.7 & 3.2 & 5.9 & 1.8 \\
\hline iso- $\mathrm{C}_{15: 0}$ & 50.7 & 41.9 & 42.6 & 37.4 & 42.0 \\
\hline anteiso- $\mathrm{C}_{15: 0}$ & 2.6 & 15.1 & 6.9 & 19.0 & 2.5 \\
\hline iso- $\mathrm{C}_{16: 0}$ & 6.3 & 9.3 & 14.7 & 5.9 & 11.5 \\
\hline iso- $\mathrm{C}_{17: 0}$ & 6.2 & 6.8 & 6.0 & 7.9 & 11.0 \\
\hline anteiso- $\mathrm{C}_{17: 0}$ & 1.3 & 7.1 & 2.6 & 9.6 & 1.2 \\
\hline iso- $\mathrm{C}_{17: 1} \omega 10 c$ & 4.0 & 2.3 & 1.1 & 0.9 & 6.8 \\
\hline \multicolumn{6}{|l|}{ Unsaturated } \\
\hline $\mathrm{C}_{16: 1} \omega 7 c$ alcohol & 10.4 & 9.0 & 11.3 & 4.2 & 15.6 \\
\hline $\mathrm{C}_{16: 1} \omega 11 c$ & 1.5 & 2.5 & 2.0 & 4.9 & 3.3 \\
\hline Summed feature $4^{\star}$ & 1.3 & 2.6 & 1.1 & 2.7 & 1.6 \\
\hline
\end{tabular}

*Summed features represent groups of two or three fatty acids that cannot be separated by the Microbial Identification System. Summed feature 4 consisted of iso- $\mathrm{C}_{17: 1} \omega 7 c$ and/or anteiso- $\mathrm{C}_{17: 1}$. were iso- $\mathrm{C}_{15: 0}(50.7 \%)$ and $\mathrm{C}_{16: 1} \omega 7 c$ alcohol $(10.4 \%)$. This fatty acid profile was similar to those of the type strains of species of the genus Lysinibacillus, although there were differences in the proportions of some fatty acids (Table 2). The major polar lipids were diphosphatidylglycerol, phosphatidylglycerol and phosphatidylethanolamine. The DNA G + C content of strain $\mathrm{XDB9}^{\mathrm{T}}$ was $37.2 \mathrm{~mol} \%$.

Mean DNA-DNA relatedness values between strain $\mathrm{XDB} 9^{\mathrm{T}}$ and the type strains of four Lysinibacillus species were in the range of 11-27\%: L. parviboronicapiens KCTC $13154^{\mathrm{T}}$ (11\%), L. sphaericus KCTC $3346^{\mathrm{T}}$ (16\%), L. fusiformis KACC $10903^{\mathrm{T}}(21 \%)$ and L. boronitolerans JCM $21713^{\mathrm{T}}$ $(27 \%)$. These values indicate that strain $\mathrm{XDB}^{\mathrm{T}}$ can be assigned to a distinct genomic species (Wayne et al., 1987). Strain $\mathrm{XDB}^{\mathrm{T}}$ is distinguishable from other species of the genus Lysinibacillus on the basis of several phenotypic differences, including boron tolerance and hydrolysis and utilization of several substrates (Table 1). Strain $\mathrm{XDB}^{\mathrm{T}}$ is similar to other species of the genus Lysinibacillus in that the predominant fatty acid is iso- $\mathrm{C}_{15: 0}$, but it is distinguishable from them in that a significant amount of iso- $\mathrm{C}_{11: 0}$ is also present (Table 2). Therefore, on the basis of differential phenotypic properties and phylogenetic and genetic distinctiveness, strain $\mathrm{XDB} 9^{\mathrm{T}}$ is sufficiently different from other Lysinibacillus species to be classified as a member of a novel taxon, for which the name Lysinibacillus xylanilyticus sp. nov. is proposed.

Description of Lysinibacillus xylanilyticus sp. nov. Lysinibacillus xylanilyticus [xy.la.ni.ly'ti.cus. N.L. n. xylanum xylan; N.L. masc. adj. lyticus (from Gr. masc. adj. 
lutikos) able to loosen, able to dissolve; N.L. masc. adj. xylanilyticus xylan-dissolving].

Cells are Gram-positive, motile and endospore-forming rods $(0.8-1.0 \times 3.0-5.0 \mu \mathrm{m})$. Colonies on TSA are dark yellow, opaque and circular with entire margins. Growth occurs at 10 and $40{ }^{\circ} \mathrm{C}$ (optimum $30{ }^{\circ} \mathrm{C}$ ), but not at 4 or $45{ }^{\circ} \mathrm{C}$, at $\mathrm{pH} 5.0$ and 9.0 , but not at $\mathrm{pH} 4.5$ or $\mathrm{pH} 9.5$ and with $0-5 \%(\mathrm{w} / \mathrm{v}) \mathrm{NaCl}$. Casein is hydrolysed, but starch and Tweens 20, 40, 60 and 80 are not. Susceptible to boron and does not grow with 50,100 or $150 \mathrm{mM}$ boron. In assays with the API ZYM system, alkaline phosphatase, acid phosphatase and naphthol-AS-BIphosphohydrolase are present, but esterase (C4), esterase lipase (C8), lipase (C14), leucine arylamidase, valine arylamidase, cystine arylamidase, trypsin, $\alpha$-chymotrypsin, $\alpha$ - and $\beta$-galactosidases, $\beta$-glucuronidase, $\alpha$ - and $\beta$ glucosidases, $N$-acetyl- $\beta$-glucosaminidase, $\alpha$-mannosidase and $\alpha$-fucosidase are absent. The predominant menaquinone is MK-7. The major fatty acids $(>10 \%$ of total fatty acids) are iso- $\mathrm{C}_{15: 0}$ and $\mathrm{C}_{16: 1} \omega 7 c$ alcohol. The cell-wall peptidoglycan type is $\mathrm{A} 4 \alpha$. The major polar lipids are diphosphatidylglycerol, phosphatidylglycerol and phosphatidylethanolamine. Other phenotypic properties are shown in Table 1.

The type strain, $\mathrm{XDB}^{\mathrm{T}}\left(=\mathrm{KCTC} 13423^{\mathrm{T}}=\right.$ CCUG $\left.57438^{\mathrm{T}}\right)$, was isolated from forest humus of Gyeryong Mountain, Taejon, Korea. The DNA G + C content of the type strain is $37.2 \mathrm{~mol} \%$.

\section{Acknowledgements}

This work was supported by the Korea Research Foundation Grant (KRF-2007-355-C00043) funded by the Korean Government (MOEHRD) and 21C Frontier Program of Microbial Genomics and Applications (grant MG05-0401-2-0) from the Ministry of Education, Science and Technology (MEST) of the Republic of Korea.

\section{References}

Ahmed, l., Yokota, A., Yamazoe, A. \& Fujiwara, T. (2007). Proposal of Lysinibacillus boronitolerans gen. nov., sp. nov., and transfer of Bacillus fusiformis to Lysinibacillus fusiformis comb. nov. and Bacillus sphaericus to Lysinibacillus sphaericus comb. nov. Int J Syst Evol Microbiol 57, 1117-1125.

Ash, C., Farrow, J. A. E., Wallbanks, S. \& Collins, M. D. (1991). Phylogenetic heterogeneity of the genus Bacillus revealed by comparative analysis of small-subunit-ribosomal RNA sequences. Lett Appl Microbiol 13, 202-206.

Claus, D. \& Berkeley, R. C. W. (1986). Genus Bacillus Cohn 1872. In Bergey's Manual of Systematic Bacteriology, vol. 2, pp. 1105-1139. Edited by P. H. A. Sneath, N. S. Mair, M. E. Sharpe \& J. G. Holt. Baltimore: Williams \& Wilkins.

Claus, D. \& Fritze, D. (1989). Taxonomy of Bacillus. In Bacillus (Biotechnology Handbooks vol. 2), pp. 5-26. Edited by C. R. Harwood. New York: Plenum.

Coughlan, M. P. \& Hazlewood, G. P. (1993). $\beta$-1,4-D-Xylan-degrading enzyme systems: biochemistry, molecular biology and applications. Biotechnol Appl Biochem 17, 259-289.
Cowan, S. T. \& Steel, K. J. (1965). Manual for the Identification of Medical Bacteria. London: Cambridge University Press.

Ezaki, T., Hashimoto, Y. \& Yabuuchi, E. (1989). Fluorometric deoxyribonucleic acid-deoxyribonucleic acid hybridization in microdilution wells as an alternative to membrane filter hybridization in which radioisotopes are used to determine genetic relatedness among bacterial strains. Int J Syst Bacteriol 39, 224-229.

Felsenstein, J. (1981). Evolutionary trees from DNA sequences: a maximum likelihood approach. J Mol Evol 17, 368-376.

Felsenstein, J. (1985). Confidence limit on phylogenies: an approach using the bootstrap. Evolution 39, 783-791.

Hall, T. A. (1999). BioEdit: a user-friendly biological sequence alignment editor and analysis program for Windows 95/98/NT. Nucleic Acids Symp Ser 41, 95-98.

Kluge, A. G. \& Farris, J. S. (1969). Quantitative phyletics and the evolution of anurans. Syst Zool 18, 1-32.

Komagata, K. \& Suzuki, K. (1987). Lipid and cell-wall analysis in bacterial systematics. Methods Microbiol 19, 161-207.

Kumar, S., Tamura, K. \& Nei, M. (2004). MEGA3: integrated software for molecular evolutionary genetics analysis and sequence alignment. Brief Bioinform 5, 150-163.

Lányí, B. (1987). Classical and rapid identification methods for medically important bacteria. Methods Microbiol 19, 1-67.

Miller, G. L. (1959). Use of dinitrosalicylic acid reagent for determination of reducing sugar. Anal Chem 31, 426-428.

Minnikin, D. E., O’Donnell, A. G., Goodfellow, M., Alderson, G., Athalye, M., Schall, A. \& Parlett, J. H. (1984). An integrated procedure for the extraction of bacterial isoprenoid quinones and polar lipids. J Microbiol Methods 2, 233-241.

Miwa, H., Ahmed, I., Yokota, A. \& Fujiwara, T. (2009). Lysinibacillus parviboronicapiens sp. nov., a low-boron-containing bacterium isolated from soil. Int J Syst Evol Microbiol 59, 1427-1432.

Nakamura, L. K., Shida, O., Takagi, H. \& Komagata, K. (2002). Bacillus pycnus sp. nov. and Bacillus neidei sp. nov., round-spored bacteria from soil. Int J Syst Evol Microbiol 52, 501-505.

Priest, F. G., Goodfellow, M. \& Todd, C. (1988). A numerical classification of the genus Bacillus. J Gen Microbiol 134, 1847-1882.

Rheims, H., Frühling, A., Schumann, P., Rohde, M. \& Stackebrandt, E. (1999). Bacillus silvestris sp. nov., a new member of the genus Bacillus that contains lysine in its cell wall. Int J Syst Bacteriol 49, 795802.

Saitou, N. \& Nei, M. (1987). The neighbour-joining method; a new method for reconstructing phylogenetic trees. Mol Biol Evol 4, 406425.

Sasser, M. (1990). Identification of bacteria by gas chromatography of cellular fatty acids, MIDI Technical Note 101. Newark, DE: MIDI Inc.

Schleifer, K. H. \& Kandler, O. (1972). Peptidoglycan types of bacterial cell walls and their taxonomic implications. Bacteriol Rev 36, 407-477.

Shaw, S. \& Keddie, R. M. (1983). A numerical taxonomic study of the genus Kurthia with a revised description of Kurthia zopfii and a description of Kurthia gibsonii sp. nov. Syst Appl Microbiol 4, 253-276.

Stackebrandt, E., Ludwig, W., Weizenegger, M., Dorn, S., McGill, T. J., Fox, G. E., Woese, C. E., Schubert, W. \& Schleifer, K.-H. (1987). Comparative $16 \mathrm{~S}$ rRNA oligonucleotide analyses and murein types of round-spore-forming bacilli and non-sporeforming relatives. J Gen Microbiol 133, 2523-2529.

Tamaoka, J. \& Komagata, K. (1984). Determination of DNA base composition by reversed-phase high-performance liquid chromatography. FEMS Microbiol Lett 25, 125-128. 
Thompson, J. D., Gibson, T. J., Plewniak, F., Jeanmougin, F. \& Higgins, D. G. (1997). The CLUSTAL_X windows interface: flexible strategies for multiple sequence alignment aided by quality analysis tools. Nucleic Acids Res 25, 4876-4882.

Timmell, T. E. (1967). Recent progress in the chemistry of wood hemicelluloses. Wood Sci Technol 1, 45-70.

Wayne, L. G., Brenner, D. J., Colwell, R. R., Grimont, P. A. D., Kandler, O., Krichevsky, M. I., Moore, L. H., Moore, W. E. C., Murray, R. G. E. \& other authors (1987). International Committee on Systematic Bacteriology. Report of the ad hoc committee on reconciliation of approaches to bacterial systematics. Int J Syst Bacteriol 37, 463-464.

Wood, P. J., Erfle, J. D. \& Teather, R. M. (1988). Use of complex formation between Congo red and polysaccharides in detection and assay of polysaccharide hydrolases. Methods Enzymol 160, 59-74.

Yoon, J.-H., Kim, H., Kim, S.-B., Kim, H.-J., Kim, W. Y., Lee, S. T., Goodfellow, M. \& Park, Y.-H. (1996). Identification of Saccharomonospora strains by the use of genomic DNA fragments and rRNA gene probes. Int J Syst Bacteriol 46, 502-505.

Yoon, J.-H., Lee, S. T. \& Park, Y.-H. (1998). Inter- and intraspecific phylogenetic analysis of the genus Nocardioides and related taxa based on 16S rRNA gene sequences. Int J Syst Bacteriol 48, 187194.

Yoon, J.-H., Kang, K. H. \& Park, Y.-H. (2003). Psychrobacter jeotgali sp. nov., isolated from jeotgal, a traditional Korean fermented seafood. Int J Syst Evol Microbiol 53, 449-454. 